\section{A 3-D Finite Element Study of the Influence of Crown-Implant Ratio on Stress Distribution}

Sandra Lúcia Dantas de Moraes ${ }^{1}$, Fellippo Ramos Verri ${ }^{2}$ Joel Ferreira Santiago Junior $^{2}$, Daniel Augusto de Faria Almeida², Caroline Cantieri de Mello², Eduardo Piza Pellizzer ${ }^{2}$
'Discipline of Complete

Denture, School of Dentistry of Pernambuco, UPE - University of Pernambuco, Recife, PE, Brazil ${ }^{2}$ Department of Dental Materials and Prosthodontics, Araçatuba School of Dentistry, UNESP - Univ Estadual Paulista, Araçatuba, SP, Brazil

Correspondence: Prof. Dr. Eduardo Piza Pellizzer, Rua José Bonifácio, 1193, 16015-050 Araçatuba, SP, Brasil. Tel: +55-18-3636-3297. e-mail: ed.pl@uol.com.br

\begin{abstract}
The purpose of this study was to assess the influence of the crown height of external hexagon implants on the displacement and distribution of stress to the implant/bone system, using the three-dimensional finite element method. The InVesalius and Rhinoceros 4.0 softwares were used to generate the bone model by computed tomography. Each model was composed of a bone block with one implant $(3.75 \times 10.0 \mathrm{~mm})$ with external hexagon connections and crowns with $10 \mathrm{~mm}, 12.5 \mathrm{~mm}$ and $15 \mathrm{~mm}$ in height. A $200 \mathrm{~N}$ axial and a $100 \mathrm{~N}$ oblique $\left(45^{\circ}\right)$ load were applied. The models were solved by the NeiNastran 9.0 and Femap 10.0 softwares to obtain the results that were visualized by maps of displacement, von Mises stress (crown/implant) and maximum principal stress (bone). The crown height under axial load did not influence the stress displacement and concentration, while the oblique loading increased these factors. The highest stress was observed in the neck of the implant screw on the side opposite to the loading. This stress was also transferred to the crown/platform/bone interface. The results of this study suggest that the increase in crown height enhanced stress concentration at the implant/bone tissue and increased displacement in the bone tissue, mainly under oblique loading.
\end{abstract}

Key Words: finite element analysis, dental prosthesis, implantsupported, biomechanics, dental implants.

\section{Introduction}

Implantology allowed the improvement of dental rehabilitation, as demonstrated by several studies reporting the success of this treatment alternative; however the overload has been considered one of the risk factors for implant longevity. Single restorations supported by external hexagon implants are relatively successful, but screw loosening has been reported as a frequent complication (1-4). Thus, the transfer and distribution of biomechanical loads applied to the implants should be controlled to enhance the function of implant-supported prostheses (5).

Considering the absence of a periodontal ligament in the implant biomechanics, the interface is rigid and direct, so the load applied to the implant/prosthesis system is directly transferred to the bone. The bone function is monitored by the physiological answer to the distribution of functional loads, resulting in modification of trabecular bone and remodeling of cortical tissue. The implant moves only because of bone elasticity, which allows movement from 3 to 5 micrometers vertically and 10 to 50 micrometers laterally (6).

Some studies describe approaches to reduce the stress transfer to bone tissue, including different diameters and lengths of implants, occlusal patterns, veneering materials, prosthetic components, implant-crown ratio, load type, material properties of implants, quality and quantity of surrounding bone and surface characteristics of implants (3,7-10).

Misch (11) stated that several factors may increase the mechanical load on an implant-supported restoration, and the increase in crown height is a relevant influence (12). Some longitudinal clinical studies of implants with high crowns reported that this factor does not jeopardize treatment predictability (13). However, other studies reported failures for the implant-crown ratio of 1.4:1. A biomechanical test examining crown height $(10,12$ and $14 \mathrm{~mm}$ ) demonstrated displacement of the highest crown only under oblique loading (14). In addition, it has been found that unfavorable crown-to-root ratio associated with parafunctional habits could lead to failure and dysfunction (15).

There is yet no consensus in the literature about the optimum height of implant-supported crowns. The aim of this 3-D finite element analysis was to evaluate the displacement and distribution of stress in the crown, screw, implant and bone with different crown-implant ratios to external hexagon implants. The null hypothesis is that increasing the height of the crown is not detrimental to the stress distribution.

\section{Material and Methods}

For this study, three 3-D models were fabricated: 
external hexagon implant $(3.75 \times 10 \mathrm{~mm})$ with $10 \mathrm{~mm}$ crown (model A), $12.5 \mathrm{~mm}$ crown (model B) and $15 \mathrm{~mm}$ crown (model $\mathrm{C}$ ), representing a section of the mandibular bone type III, an external hexagon implant and a single fixed crown, respectively. The bone model consisted of trabecular bone in the center surrounded by $1 \mathrm{~mm}$ of cortical bone corresponding to the region of the second mandibular molar.

The geometries of the trabecular and cortical bone tissues were obtained from a transversal computed tomography of the 3-D virtual models by transversal tomographic slices. Then, the image was transferred to the software InVesalius (CTI, Campinas, SP, Brazil) and then to Rhinoceros 4.0 (NURBS Modeling for Windows, Seattle, WA, USA) to simplify the geometry and improve the drawing. The implant geometries were based on a commercial system (Conexão Sistemas de Prótese Ltda., Arujá, SP, Brazil) with an external hexagon implant with $10 \mathrm{~mm}$ in length and $3.75 \mathrm{~mm}$ in diameter. The UCLA abutment was also used. The geometry of all implants (threads) and the prosthetic components (occlusal surface) were simplified by the SolidWorks 2006 (SolidWorks Corp, Waltham, MA, USA) and Rhinoceros 4.0 (NURBS Modeling for Windows) softwares.

Three metal-ceramic crowns $(10 \mathrm{~mm}, 12.5 \mathrm{~mm}$ and 15 $\mathrm{mm}$ ) were modeled on the prosthetic components with different heights (9). The occlusal surface was scanned (MDX-20; Roland DG, São Paulo, SP, Brazil) from an artificial mandibular second molar (Odontofix Indústria e Comércio de Material Odontológico Ltda, Ribeirão Preto, SP, Brazil). After modeling, the implant-crown assembly was inserted

Table 1. Nodes and elements

\begin{tabular}{lcc}
\hline Model & Nodes & Elements \\
\hline A & 432,738 & 287,331 \\
B & 446,288 & 295,607 \\
C & 434,122 & 287,534 \\
\hline
\end{tabular}

Table 3. Maximum displacement value (level of crowns)

\begin{tabular}{llccc}
\hline Crown Height & \multicolumn{2}{c}{ Axial Load $(200 \mathrm{~N})$} & \multicolumn{2}{c}{ Oblique load $(100 \mathrm{~N})$} \\
\hline Crown & Crown & Increase $(\%)^{*}$ & Crown & Increase (\%) \\
$10 \mathrm{~mm}(\mathrm{a})$ & $9 \mu \mathrm{m}$ & - & $126 \mu \mathrm{m}$ & - \\
$12.5 \mathrm{~mm}(\mathrm{~b})$ & $9 \mu \mathrm{m}$ & - & $171 \mu \mathrm{m}$ & 35.71 \\
$15 \mathrm{~mm}(\mathrm{c})$ & $9 \mu \mathrm{m}$ & - & $233 \mu \mathrm{m}$ & 84.92 \\
Average & $9 \mu \mathrm{m}$ & - & $176 \mu \mathrm{m}$ & 39.68 \\
\hline
\end{tabular}

*Increase (\%) column shows the increase in displacement: Crown (b) or (c) - Crown $10 \mathrm{~mm}$ (a) / Crown $10 \mathrm{~mm}$ (a) x 100\%. centrally into the bone block. The crown/implant ratio (11.25-1.5) was calculated dividing the crown height by the implant length. Then, the geometries were transferred to the finite element software FEMAP 10.0 (Siemens PLM Software Inc., Santa Ana, CA, USA) to generate the finite element meshes with parabolic solid elements. The total number of nodes and elements for the external hexagon implants are described in Table 1 . The mechanical properties of each material, Young's modulus and Poisson's coefficient were attributed to the meshes according to values described in the literature (16) (Table 2).

All materials were considered isotropic, linearly elastic and homogeneous. Bonded contact was established at porcelain/metal, implant/cortical bone, cortical/trabecular bone interfaces, while the contact interface between crown and implant was considered as juxtaposed. According to the literature (17), $200 \mathrm{~N}$ axial and $100 \mathrm{~N}$ oblique loads were applied $\left(45^{\circ}\right)$ on balancing cusp. The load was applied on four cusps for axial load ( $50 \mathrm{~N}$ ) and two lingual cusps (50 N) for oblique load in an area of about $0.17 \mathrm{~mm}^{2}$.

Finally, the analysis was generated by the FEMAP 10.0 finite element software and transferred to the NeiNastran 9.0 (Noran Engineering, Westminster, CO, USA) software for calculation in a workstation (Sun Microsystems Inc., São Paulo, SP, Brazil). Results were entered again in FEMAP 10.0 software for visualization and post-processing of the maps.

Table 2. Mechanical properties

\begin{tabular}{lcc}
\hline Structures & $\begin{array}{c}\text { Modulus of } \\
\text { elasticity }(\mathrm{GPa})\end{array}$ & Poisson ratio (v) \\
\hline Trabecular bone & 1.37 & 0.30 \\
Cortical bone & 13.7 & 0.30 \\
Implant (titanium) & 110.0 & 0.35 \\
NiCr alloy & 206.0 & 0.33 \\
Feldspathic porcelain & 82.8 & 0.35 \\
\hline
\end{tabular}

Data obtained from Santiago Jr. et al., 2013 (Reference \#16).

Table 4. Maximum displacement value (level of bone)

\begin{tabular}{lcccc}
\hline Crown Height & \multicolumn{2}{c}{ Axial Load $(200 \mathrm{~N})$} & \multicolumn{2}{c}{ Oblique Load $(100 \mathrm{~N})$} \\
\hline Crown & Crown & Increase (\%) & Crown & Increase (\%)* \\
$10 \mathrm{~mm}(\mathrm{a})$ & $5 \mu \mathrm{m}$ & - & $15 \mu \mathrm{m}$ & - \\
$12.5 \mathrm{~mm}(\mathrm{~b})$ & $5 \mu \mathrm{m}$ & - & $21 \mu \mathrm{m}$ & 40 \\
$15 \mathrm{~mm}(\mathrm{c})$ & $6 \mu \mathrm{m}$ & - & $29 \mu \mathrm{m}$ & 93.3 \\
Mean & $5.33 \mu \mathrm{m}$ & - & $21.66 \mu \mathrm{m}$ & 44.4 \\
\hline
\end{tabular}

*Increase (\%) column shows the increase in displacement: Crown (b) or (c) - Crown $10 \mathrm{~mm}$ (a) / Crown $10 \mathrm{~mm}$ (a) x 100\%. 


\section{Results}

The results were plotted on maps of displacement, von Mises stress and maximum principal stress.

\section{Analysis of General Displacement Maps}

Comparing the general displacement maps of the models $A, B$ and $C$, greater displacement was observed in the lingual surface of the crown when the height was increased for both axial and oblique loadings. Although such increase in displacement was irrelevant under axial forces, the displacement of the 15-mm crown was about twice that of the 10-mm crown under oblique loading, as shown in Table 3. However, the bone tissue exhibited a displacement of $15 \mu \mathrm{m}(\mathrm{A}), 21 \mu \mathrm{m}$ (B) and $29 \mu \mathrm{m}$ (C) for the three crowns, respectively, under oblique loading (Table 4).

\section{Implant-Crown-Screw}

For the axial load (Fig. 1), the highest stress was concentrated in the cervical region of the crowns, implant/ framework interface, implant platform and first threads of the implant, with a higher value on the lingual surface.

For the oblique load (Fig. 2), the highest stress was concentrated in the neck of the screw on the side opposite to the loading, on the crown/implant platform interface at the loading side, on the region between the implant platform and second thread, and on the cervical third of the crown following the loading direction. It was observed that the stress concentration in the screw and implant/ prosthesis interface increased as the crown became higher. Comparing the stress distributions, the $15-\mathrm{mm}$ crowns exhibited a 3 times greater area of stress concentration than the $10-\mathrm{mm}$ crown under oblique loading.

\section{Screw}

Comparing the axial and oblique loads, the highest stress was concentrated in the neck of the screw in all models (Figs. 3 and 4). The pattern of stress distribution was not similar for both types of loadings. Higher stress was produced when an oblique load (Fig. 4) was applied, and the crown height corresponded with large size of the stress concentration area.

\section{Maximum Principal Stress}

Cortical Bone: The maximum principal stress was evaluated only for the bone tissue due to the critical characteristic of tension/compression of this structure. For the axial loading (Fig. 5), the maps of maximum principal stress were created for cortical bone in the models. The areas of stress concentration were at the bone/implant interfaces with compression in the superior region and tensile in the inferior region. In this situation, the area of stress concentration is not influenced by the increase in crown height. For the oblique loading (Fig. 6), the pattern of stress distribution presented compression in the direction of loading and tension at the opposite side. However, it was observed that the crown height in the models $B$ and $C$ corresponded with the large size of the area and magnitude of stress. It was also verified that the intrusive forces remained constant while the tensile forces increased with higher crowns. The tensile forces were 3 times and 1.5 times greater in models $C$ and $B$ respectively, in comparison with model $A$. For the inferior view, the area of stress concentration was 2 times greater in models $B$ and $\mathrm{C}$ than in model $\mathrm{A}$.

Trabecular Bone: The maps of maximum principal stress show the effects of the trabecular bone under axial load. The area of maximum compressive stress was observed at the implant apex in all models.

No significant difference was observed for axial loading. For oblique loading, the tensile stress increased from model A to model $\mathrm{C}$ with greater area in the loading direction and smaller area at the opposite side (buccal surface).

\section{Discussion}

The increase in crown height was not important for the displacement increase under axial loading, but relevant for oblique loading. Gross (6) reported that the micromovement of the implant is minimum and within the elastic limit of the bone, which ranges from 3 to $5 \mu \mathrm{m}$ vertically and from 10 to $50 \mu \mathrm{m}$ laterally. It has also been suggested that osseointegration may fail when this limit is trespassed. However, the limits reached in model C (15$\mathrm{mm}$ crown) did not jeopardize osseointegration since they were restricted to the crown. The values ranged from 14 to $29 \mu \mathrm{m}$, which is within the micromovement limit from 10 to $50 \mu \mathrm{m}$ in the bone tissue. Although this result did not reach the bone limit, the micromovement associated with the stress in the crown may overload the screw and result in screw loosening or fracture.

The null hypothesis established for this study was rejected, the results of the general map demonstrated insignificant stress concentration when the crown height increased from 10 to $15 \mathrm{~mm}$ under axial load. This is in agreement with the results of a previous study that found that the load applied on the long axis of the implant does not increase the stress in bone tissue (9).

For the oblique load, however, the stress concentration in the 15-mm crown was almost twice that in the $10-\mathrm{mm}$ crown. This may be explained by the theoretical analyses of Rangert et al. (2), who suggested that axial loads are more favorable for uniform stress distribution surrounding the implant, while the oblique forces generate a severe moment. Similarly, Papavasiliou et al. (10) demonstrated that oblique forces increased the stress concentration in 
the implant and bone. These results are also in accordance with the literature that describes the influence of increase in crown height on the transference of occlusal forces $(9,11,13,15,18-24)$.

Considering the implant-crown-screw assembly, the highest stress concentration was observed at the interface of matching materials. Although the stress distribution was similar for axial loading, the stress concentration was proportional to the crown height for oblique loading. Similar results have been reported in a study that recorded higher stress concentration from the interfaces up to the first or second threads of the external hexagon implants (5).

It is important to highlight that the screw exhibited the highest stress concentration, mainly under oblique loading, which increased with higher crowns. This result is in agreement with Rangert et al. (2), who described
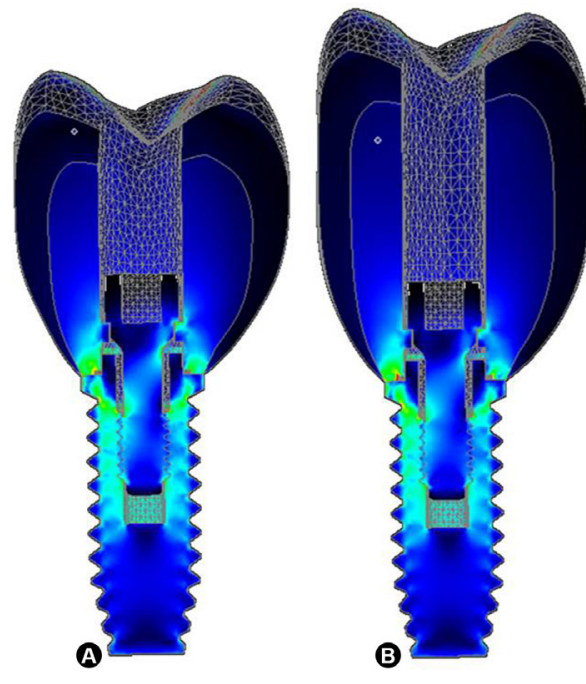

Axial Load
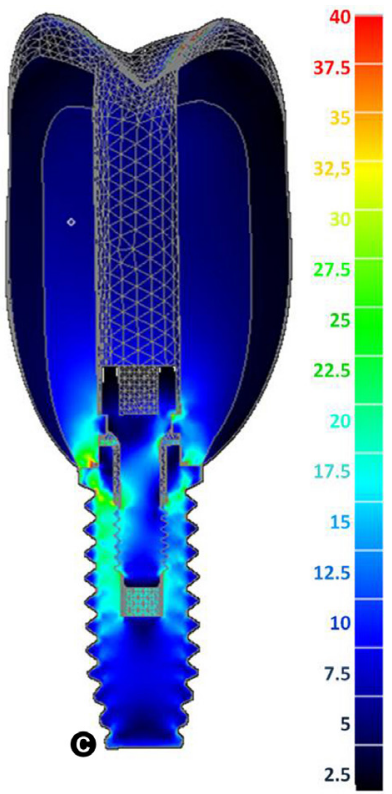

Figure 1. Crowns $10 \mathrm{~mm}(\mathrm{~A}), 12.5 \mathrm{~mm}(\mathrm{~B})$ and $15 \mathrm{~mm}$ (C) - axial loading.
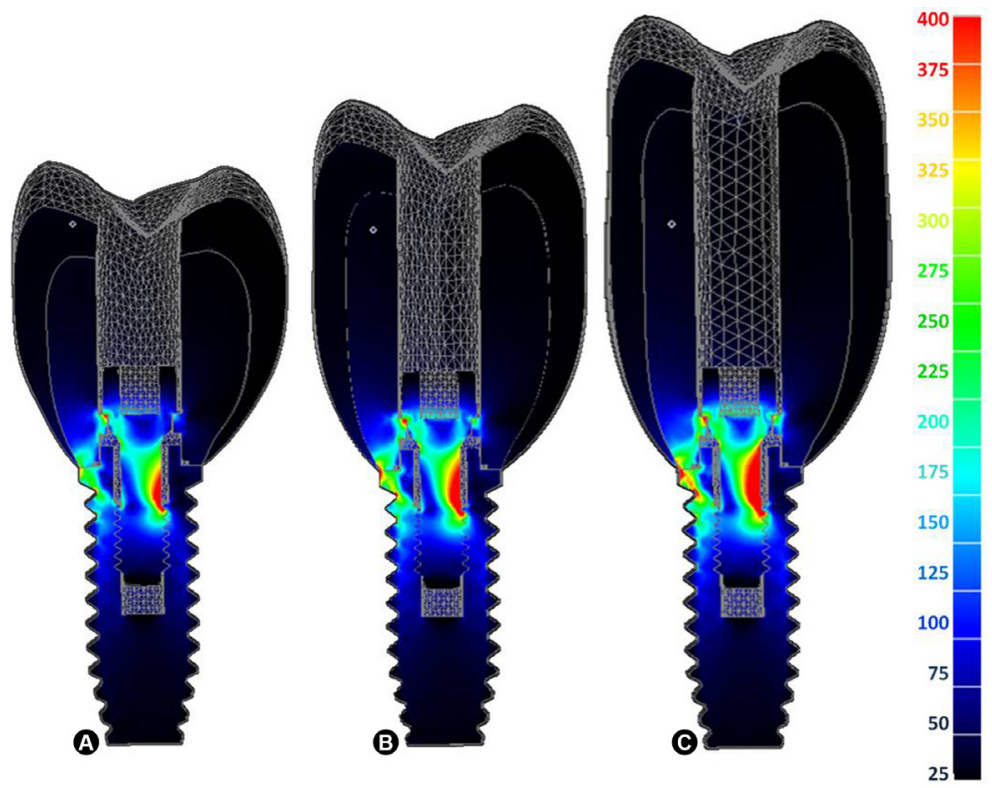

Oblique Load 
the retention screw as the weakest point among the components of the Branemark implant system. Thus, overloading on the screw commonly results in loosening or fracture $(1,3,24,25)$.

Considering only the implants, the present results demonstrated that the highest stress concentration was in the platform and first thread of the implant for oblique loads, and it was proportional to the crown height. These data were confirmed by Papavasiliou et al. (10), who demonstrated that the stress is usually concentrated in the regions with materials of different elastic modulus.

This study considered the option to use standard diameter and length implant $(3.75 \times 10 \mathrm{~mm})$ and UCLA abutment. This association is one of the most used configurations. Literature suggests that use of wide diameter implant could benefit the stress distribution in the analyzed region (16). However, in some clinical situations, there is no adequate thickness of the bone tissue, thus it is necessary to use regular diameter, and consequently, the crown increase is harmful.

In all cortical bone models, the areas of compressive and tensile stress were located throughout the peri-implant region, and the values were within the physiological limits described in the literature for maximum resistance

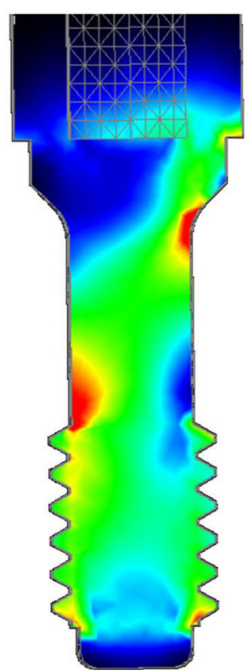

(4)

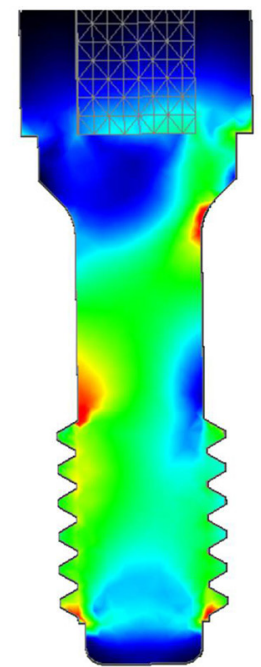

B

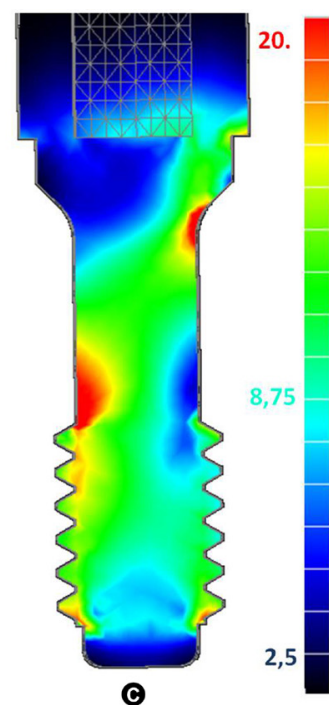

○

Figure 3. Screw section - axial loading. Crowns $10 \mathrm{~mm}$ (A), $12.5 \mathrm{~mm}$ (C) and $15 \mathrm{~mm}$ (C).

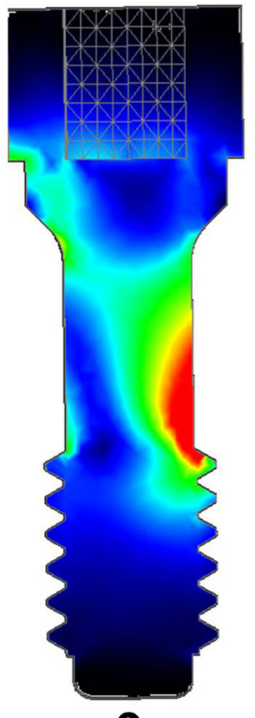

A

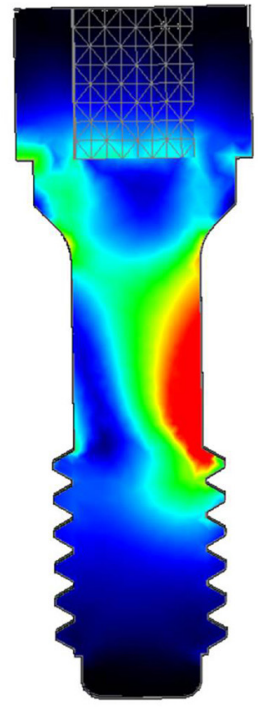

B

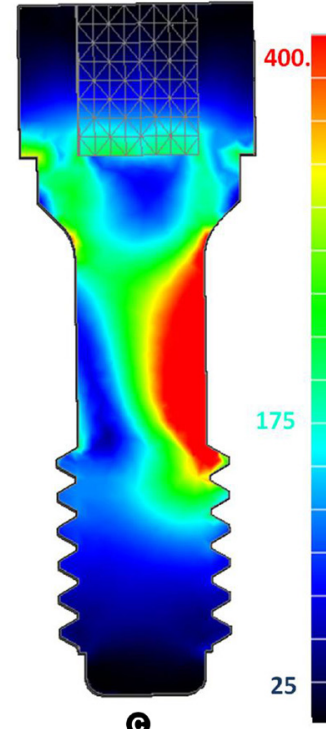

o 
of the human cortical bone: from 140 to $170 \mathrm{MPa}$ under compression and from 72 to $76 \mathrm{MPa}$ under tension, with an elastic limit of approximately $60 \mathrm{MPa}$ (10). For all trabecular bone models under oblique loading, the stress in the compression areas varied from $-0.688 \mathrm{MPa}$ to -0.0625 $\mathrm{MPa}$ while in the tension areas stress varied from $0.25 \mathrm{MPa}$ to $1 \mathrm{MPa}$, which means that all values remained within the 22 to $28 \mathrm{MPa}$ range (10). Although, theoretically, the present data would not surpass the bone threshold, Nissan et al. (12) stated that a crown height greater than of 15 $\mathrm{mm}$ is considered biomechanically unfavorable and the obtained results revealed the worst situation for the $15 \mathrm{~mm}$ crown. Thus, the continuous effect of this stress magnitude on the system may not lead to bone resorption, but may result in other prosthetic complications, such as overload on the occlusal screw.

Finally, it is important to perform a rigorous occlusal adjustment to transfer the centric contacts toward the long axis of the implant, since such contacts allow better stress distribution at the bone/implant interface. This approach may create only functional contacts during the eccentric movements to avoid oblique forces that may increase the
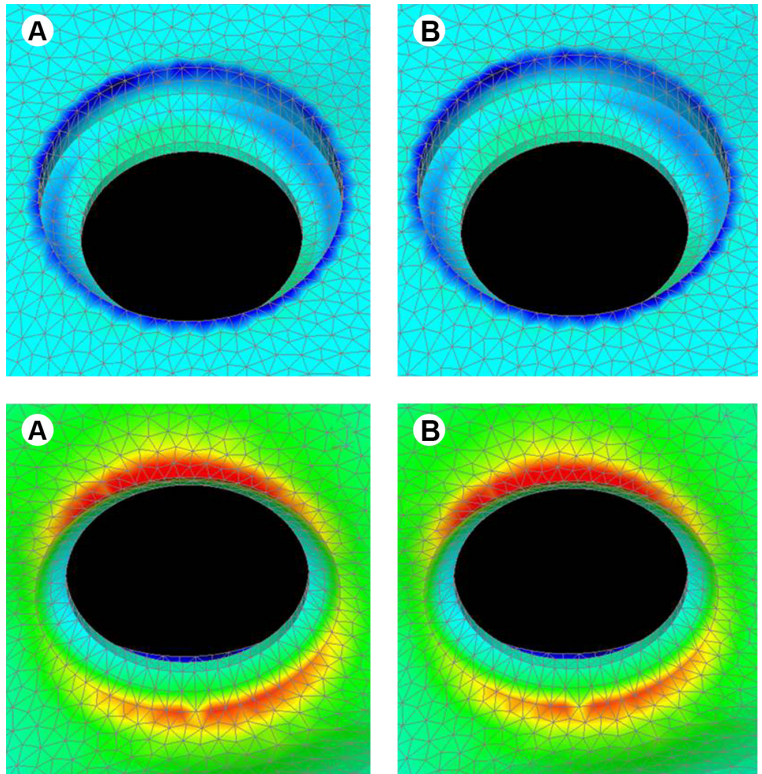
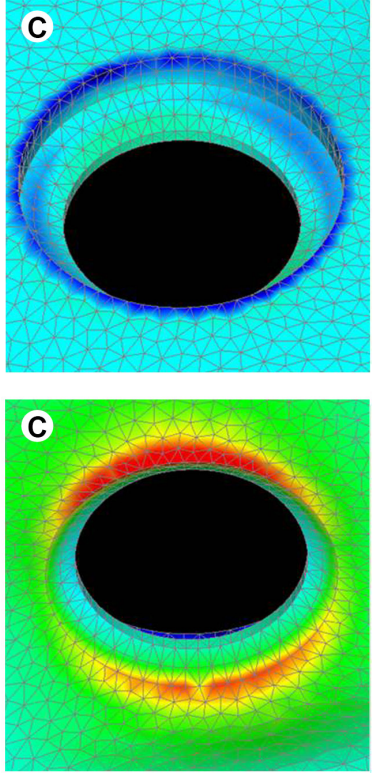

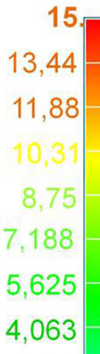

2,5

Figure 5. Maximum principal stress. Cortical bone - axial loading. Crowns $10 \mathrm{~mm}$ (A), $12.5 \mathrm{~mm}$ (C) and $15 \mathrm{~mm}$ (C).
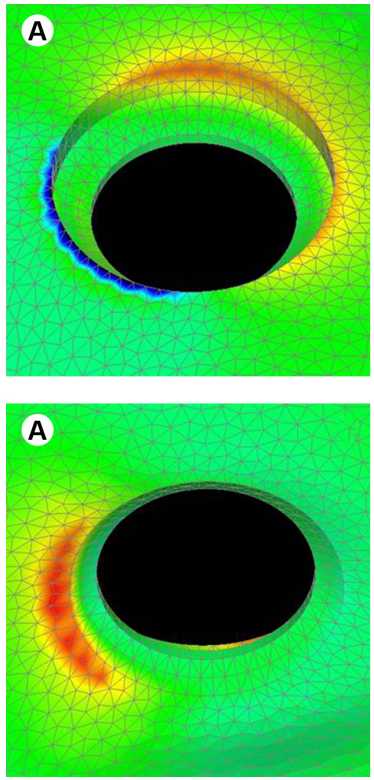
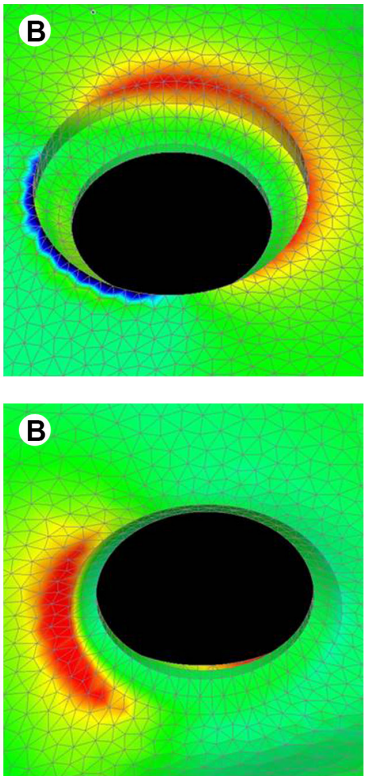
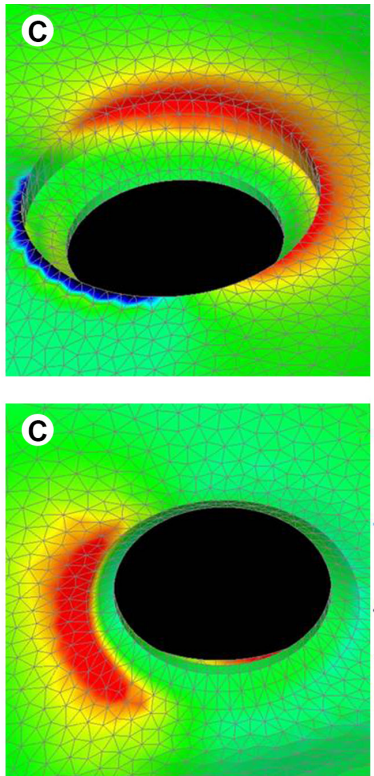

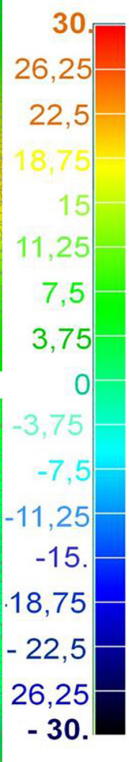

Figure 6. Maximum principal stress. Cortical bone - oblique loading. $10 \mathrm{~mm}$ (A), $12.5 \mathrm{~mm}$ (C) and $15 \mathrm{~mm}$ (C). 
stress in the surrounding structures. All these factors are important since overload generated during oblique loading and associated to other biomechanical and systemic factors may lead to the failure of osseointegration.

The finite element method has limitations inherent to simulation computer studies: for example, the properties of the tested materials were considered isotropic, homogeneous, and linear, differing from the clinical situation of bone tissue. However, this methodology is supported by literature of bone biomechanics and reveals complementary data to clinical follow up. According to the methodology and results of the present study, it was concluded that the increase in the crown height enhances stress concentration at the implant/bone tissue and increases displacement of the bone tissue, mainly under oblique loading.

\section{Resumo}

A proposta deste estudo foi avaliar a influência da altura da coroa de implantes de hexágono externo sobre o deslocamento e distribuição de tensões para o sistema implante/osso utilizando o método de elementos finitos. Os softwares InVesalius e Rhinoceros 4.0 foram usados para gerar o modelo de osso por meio de uma tomografia computadorizada. Cada modelo foi composto de um bloco ósseo com um implante $(3.75 \times 10.0$ $\mathrm{mm}$ ) com conexão de hexágono externo e coroas de $10 \mathrm{~mm}, 12.5 \mathrm{~mm}$ e $15 \mathrm{~mm}$ em altura. Uma carga axial de $200 \mathrm{~N}$ e oblíqua $\left(45^{\circ}\right)$ de $100 \mathrm{~N}$ foram aplicadas. Os modelos foram resolvidos pelo software NeiNastram 9.0 e Femap 10.0 para obtenção dos resultados que foram visualizados por meio de mapas de deslocamento, de von Mises (coroa/implante) e tensão máxima principal (osso). A altura da coroa sob carga axial não influenciou o deslocamento e concentração de tensões, enquanto que a carga oblíqua aumentou a ação destes fatores. A maior concentração de tensões foi observada no pescoço do parafuso do implante no lado oposto à aplicação de carga. Esta tensão foi transferida para a interface coroa/plataforma/interface óssea. Os resultados deste estudo sugerem que o aumento da coroa amplia a concentração de tensões no tecido ósseo/ implante, aumentando o deslocamento no tecido ósseo, principalmente sob carga obliqua.

\section{Acknowledgments}

The authors acknowledge The São Paulo State Research Foundation (FAPESP, Grant 2009/16164-7), Three-Dimensional Technologies, Renato Archer Information Technology Center-CTI, Campinas, SP, Brazil, and Conexão Sistemas de Prótese Ltda., São Paulo, SP, Brazil.

\section{References}

1. Pjetursson $B E$, Tan $K$, Lang NP, Brägger $U$, Egger $M$, Zwahlen $M$. A systematic review of the survival and complication rates of fixed partial dentures (FPDs) after an observation period of at least 5 years. Clin Oral Implants Res 2004;15:667-676.

2. Rangert BO, Jemt $\mathrm{T}$, Jorneus L. Force and moments on Branemark Implants. Int J Oral Maxillofac Implants 1989;4:241-247.

3. Schwarz MS. Mechanical complications of dental implants. Clin Oral Implants Res 2000;11:156-158.

4. Barbosa GS, Silva-Neto JP, Simamoto-Júnior PC, Neves FD, Mattos M da $G$, Ribeiro RF. Evaluation of screw loosening on new abutment screws and after successive tightening. Braz Dent J 2011;22:51-55.

5. Cehreli M, Duyck J, De Cooman M, Puers R, Naert I. Implant design and interface force transfer: a photoelastic and strain-gauge analysis. Clin
Oral Implants Res 2004;15:249-257.

6. Gross MD. Occlusion in implant dentistry: a review of the literature of prosthetic determinants and current concepts. Aust Dent J 2008;53:6068.

7. Teixeira AB, Beja GB, Shimano AC, Macedo AP, Oliscovicz NF, Reis AC. Influence of the ultimate torsion on the geometry of dental implants. Braz Dent J 2013;24:213-217.

8. Holmgren EP, Seckinger RJ, Kilgren LM, Mante F. Evaluating parameters of osseointegrated dental implants using finite element analysis: a two dimensional comparative study examining the effect of implant diameter, implant shape, and load direction. J Oral Implantol 1998;24:80-88.

9. Misch CE, Goodacre CJ, Finley JM, Misch CM, Marinbach M, Dabrowsky T, et al.. Consensus conference panel report: crown-height space guidelines for implant dentistry-part 1. Implant Dent 2005;14:312318.

10. Papavasiliou G, Kamposiora P, Bayne SC, Felton DA. Three dimensional finite element analysis of stress distribution around single tooth implants as a function of bony support prosthesis type, and loading during function. J Prosthet Dent 1996;76:633-640.

11. Misch CE. Short dental implants: a literature review and rationale for use. Dent Today 2005;24:64-66,68.

12. Nissan J, Ghelfan O, Gross O, Priel I, Gross M, Chaushu G. The effect of crown/implant ratio and crown height space on stress distribution in unsplinted implant supporting restorations. J Oral Maxillofac Surg 2011;69:1934-1939.

13. Rokni S, Todescan R, Watson P, Pharoah M, Adegbembo AO, Deporter $D$. An assessment of crown-to-root ratios with short sintered poroussurfaced implants supporting prostheses in partially edentulous patients. Int J Oral Maxillofac Implants 2005;20:69-76.

14. Kwan N, Yang S, Guillaume D, Aboyoussef H, Ganz SD, Weiner S. Resistance to crown displacement on a hexagonal implant abutment. Implant Dent 2004;13:112-119.

15. Fugazzotto PA, Beagle JR, Ganeles J, Jaffin R, Vlassis J, Kumar A. Success and failure rates of $9 \mathrm{~mm}$ or shorter implants in the replacement of missing maxillary molars when restored with individual crowns: prelimary results 0 to 84 months in function: a retrospective study. J Periodontol 2004;75:327-332.

16. Santiago Jr JF, Pellizzer EP, Carvalho PSP, Verri FR. Stress analysis in bone tissue around single implants with different diameters and veneering materials: A 3-D finite element study. Mater Sci Eng C 2013;33:4700-4714.

17. Morneburg TR, Proschel PA. Measurement of masticatory forces and implant forces and implant loads: a methodologic clinical study Int J Prosthodont 2002;15:20-27.

18. Birdi H, Schulte J, Kovacs $A$, Weed M, Chuang SK. Crown-to-implant ratios of short-length implants. J Oral Implantol 2010;36:425-433.

19. Blanes RJ, Bernard JP, Blanes ZM, Belser UC. A 10-year prospective study of ITI dental implants placed in the posterior region. I: Clinical and radiographic results. Clin Oral Implants Res 2007;18:699-706.

20. Gomez-Polo M, Bartens F, Sala L, Tamini F, Celemin A, Del Rio J. The correlation between crown-implant ratios and marginal bone resorption: a preliminary clinical study. Int J Prosthodont 2010;23:3337.

21. Salvi GE, Brägger U. Mechanical and technical risks in implant therapy. Int J Oral Maxillofac Implants 2009;24:69-85.

22. Schulte J, Flores AM, Weed M. Crown-to-implant ratios of single tooth implant-supported restorations. J Prosthet Dent 2007;98:1-5.

23. Tawil G, Aboujaoude N, Younan R. Influence of prosthetic parameters on the survival and complication rates of short implants. Int J Oral Maxillofac Implants 2006;21:275-282.

24. Urdaneta RA, Rodriguez S, McNeil DC, Weed M, Chuang SK. The effect of increased crown-to-implant ratio on single-tooth locking-taper implants. Int J Oral Maxillofac Implants 2010;25:729-743.

25. Ekfeldt A, Carlsson GE, Börjesson G. Clinical evaluation of single-tooth restorations supported by osseointegrated implants: a retrospective study. Int J Oral Maxillofac Implants 1994;9:179-183.

Received July 6, 2013 Accepted October 10, 2013 